\title{
Potensi Bahaya Gunung Api Terhadap Calon Tapak PLTN, Studi Kasus: Gunung Api Semadum, Kalimantan Barat.
}

\author{
Fuad Nur Hussein', I Gde Sukadana ${ }^{\star 2}$, Rachman Fauzi², Hill Gendoet Hartono', Sunarko³, Tyto \\ Baskara Adimedha ${ }^{2}$, Alfian Maulana Anwar ${ }^{1}$ \\ ${ }^{1}$ Program Studi Teknik Geologi, Fakultas Teknologi Mineral, Institut Teknologi Nasional Yogyakarta, Indonesia \\ ${ }^{2}$ Pusat Teknologi Bahan Galian Nuklir, BATAN, JI. Lebak Bulus Raya No. 09, Jakarta, 12440, Indonesia \\ ${ }^{3}$ Pusat Kajian Sistem Energi Nuklir-BATAN, JI. Kuningan Barat Mampang Prapatan, Jakarta 12710, Indonesia
}

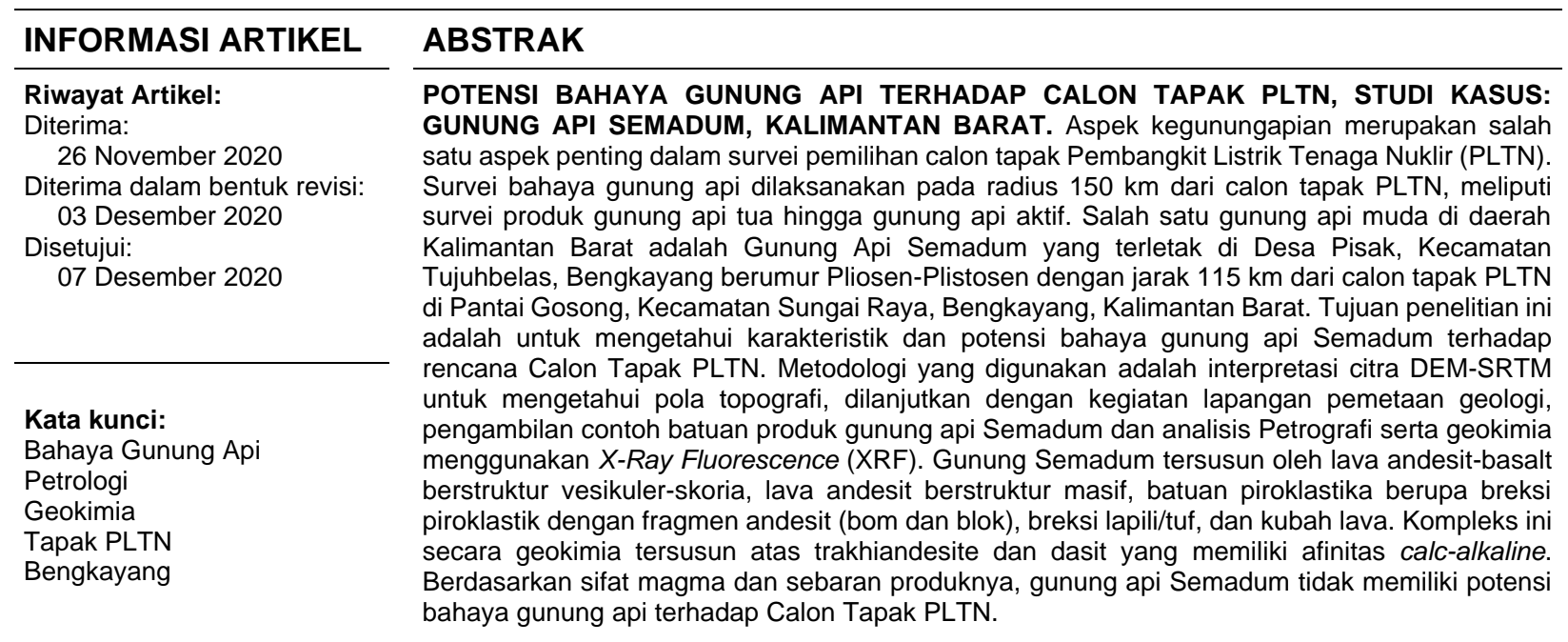

\begin{abstract}
THE POTENTIAL OF VOLCANIC HAZARD FOR NPP SITE CANDIDATE, CASE STUDY: SEMADUM VOLCANO, WEST KALIMANTAN. The volcanic hazards aspect is one of the important aspects of the selection step of the Nuclear Power Plant (NPP) site candidates survey. The volcanic hazards survey was carried out with a radius of $150 \mathrm{~km}$ from the proposed NPP candidate site, covering surveys of old volcanic products to the recent active volcanoes. One of the youngest volcanoes in the West Kalimantan area is the Semadum volcano located in Pisak Village, Tujuhbelas District, Bengkayang with Pliocene-Pleistocene age, $115 \mathrm{~km}$ from the prospective NPP candidate site at Gosong Beach, Sungai Raya District, Bengkayang, West Kalimantan. The purpose of this study was to determine the characteristics and potential hazards of the Semadum volcano regarding the NPP Site Candidate. The methodology used is the interpretation of DEM-SRTM images to determine topographic patterns, followed by geological mapping field activities, sampling of Semadum volcanic rock products, and Petrographic and geochemical analysis using X-Ray Fluorescence (XRF). Mount Semadum is composed of andesite-basalt lava with a vesicular-scoria structure, massive andesite lava, pyroclastic rocks in the form of pyroclastic breccias with andesite fragments (bombs and blocks), lapilli/tuff breccias, and lava domes. Based on geochemistry data, this complex is composed of trachyandesite and dacite rock with calk-alkaline affinity. Based on the nature of magma and the distribution of its products, the Semadum volcano does not have a potential volcanic hazard to the prospective NPP candidate site.

Keywords: Volcanic hazards, Petrology, Geochemistry, NPP Site, Bengkayang
\end{abstract}

(c) 2020 Jurnal Pengembangan Energi Nuklir. All rights reserved

\section{PENDAHULUAN}

Energi nuklir mempunyai potensi besar untuk menjadi tulang punggung energi baru terbarukan (EBT) di masa yang akan datang, dan diharapkan akan menjadi faktor pengungkit yang signifikan dalam pemenuhan energi listrik

* Penulis korespondensi

E-mail: sukadana@batan.go.id nasional, terlebih lagi teknologi nuklir dapat digolongkan ke dalam teknologi bersih (clean technology), yang dapat berperan penting dalam menggerakkan roda ekonomi nasional dan mengurangi emisi gas rumah kaca. Sebagai tahap awal penyediaan data infrastruktur suatu PLTN adalah kesiapan tapak PLTN yang 
dilakukan dari tahap pra-survei, survei dan evaluasi tapak.

Hasil pra-survei terdahulu mendapati bahwa pada pesisir pantai daerah Kalimantan Barat terdapat beberapa lokasi yang memenuhi kriteria sebagai lokasi calon tapak PLTN[1], diantaranya Pantai Simping, Pantai Batu Belah dan Pantai Gosong (Gambar 1). Lokasi interest di Kalimantan Barat juga sangat dihindari dari lahan gambut[2][3].

Pada tahun 2019, pemerintah Provinsi Kalimantan Barat mengusulkan calon tapak difokuskan ke daerah Pantai Gosong, Kecamatan Sungai Raya, Bengkayang, Kalimantan Barat. Oleh sebab itu, sejak tahun 2020 direncanakan suatu program Prioritas Riset Nasional (PRN) pembangunan pembangkit listrik tenaga nuklir di wilayah tersebut. Sebagai fasilitas berisiko tinggi, pemanfaatan nuklir melalui pembangunan sebagai sebuah PLTN perlu mempertimbangkan faktor keselamatan dari kemungkinan ancaman fenemonena geologi sebagai potensi ancaman bahaya yang dapat mengganggu instalasi dan operasioanal reaktor. Oleh karena itu, survei tapak berkaitan dengan persiapan atau pemilihan lokasi tapak perlu dilakukan sebagai langkah antisipasi terhadap potensi ancaman bahaya geologi. Program survei tapak aspek kegunungapian perlu dilakukan untuk memastikan keselamatan PLTN dari seluruh aspek bahaya gunungapi[1]. Penelitian ini bertujuan untuk mengetahui karakteristik mineralogi dan geokimia serta potensi bahaya Gunung Api Semadum sebagai salah satu dasar dalam memberikan masukan pada dasar desain bangunan PLTN apabila terdapat kemungkinan dampak bahaya kegunungapian yang mencapai daerah tapak. Studi aspek kegunungapian dilakukan pada radius $150 \mathrm{~km}$ dari lokasi tapak. Pada radius tersebut terdapat fenomena kegunungapian yang berumur muda PliosenPlistosen yang disusun oleh lava andesit-basalt berstruktur vesikuler-skoria, lava andesit berstruktur masif, batuan piroklastika berupa breksi piroklastik dengan fragmen andesit (bom dan blok), breksi lapili/tuf, tuf, kubah lava, batuan basalt dan dikelilingi batuan non gunung api berupa batupasir kuarsa berumur sangat tua. Hal tersebut menjadi aspek menarik untuk dikaji. Lokasi penelitian difokuskan pada Gunung Api Semadum terletak di Desa Pisak, Kecamatan Tujuhbelas, Kabupaten Bengkayang, Provinsi Kalimantan Barat (Gambar 2).

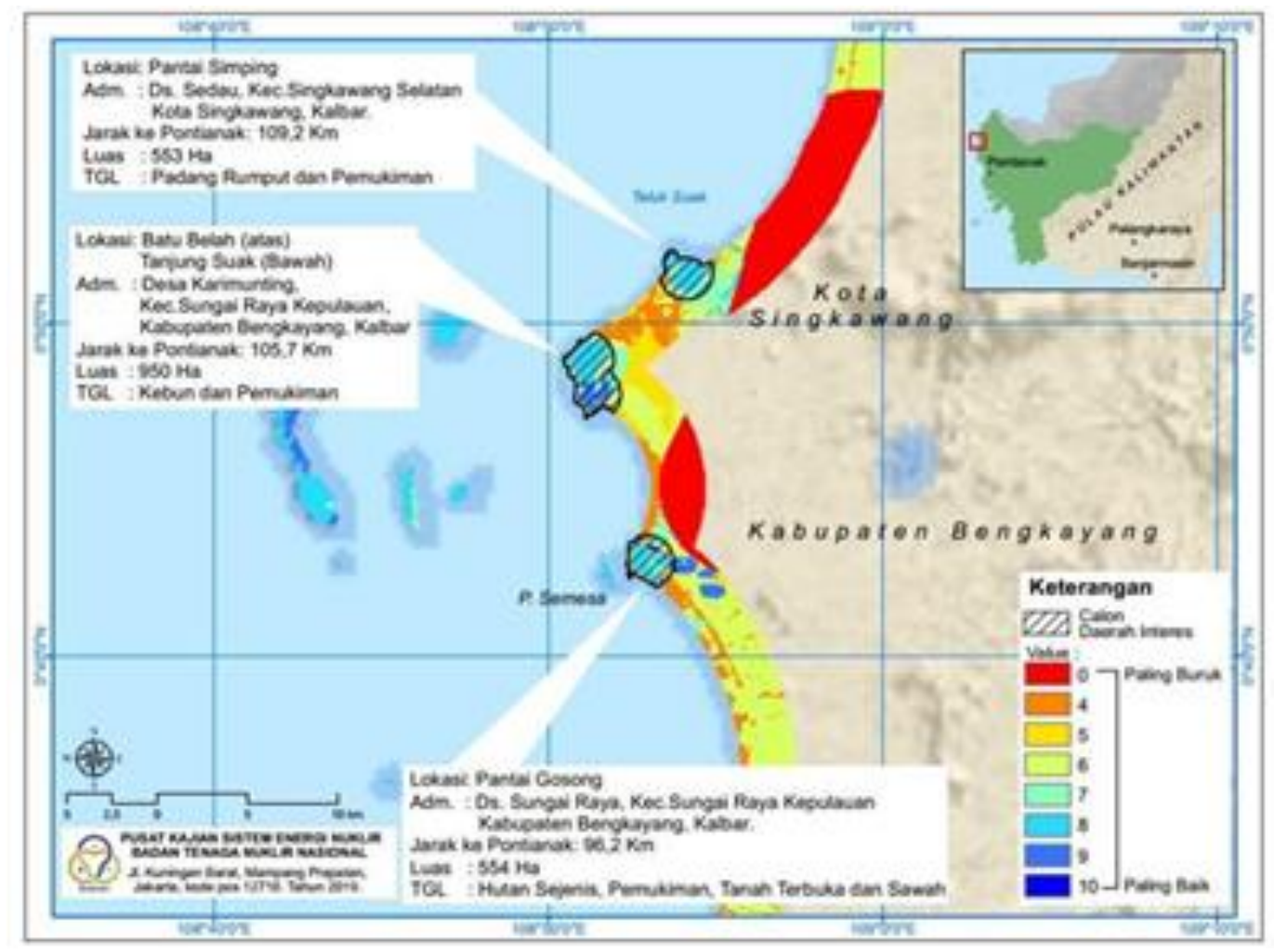

Gambar 1. Lokasi rencana calon tapak hasil pra-survei. 


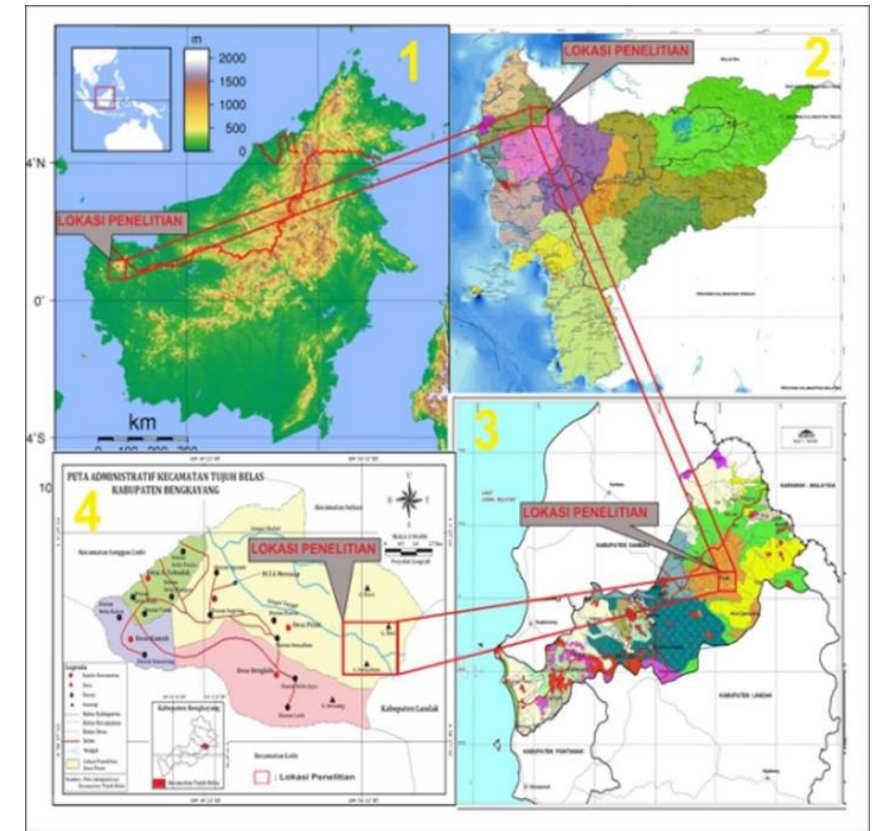

Gambar 2. Lokasi penelitian Gunung Semadum, Desa Pisak, Kecamatan Tujuh belas, Bengkayang, Kalimantan Barat.

\section{GEOLOGI REGIONAL}

Tataan tektonik Pulau Kalimantan tidak lepas dari sangat kompleknya tataan tektonik di Indonesia. Banyak model tektonik yang sudah dibuat oleh peneliti sebelumnya untuk menjelaskan evolusi tektonik Pulau Kalimantan (Borneo). Tektonik Indonesia termasuk Kalimantan tidak lepas dari tataan tektonik Asia Tenggara[4], dan rekonstruksi tektonik Pulau Kalimantan hingga saat ini masih banyak dibahas dan menjadi fenomena yang tidak banyak diteliti, salah satunya adalah ringkasan pemodelan dari perkembangan tektonik Indonesia (Gambar 3)[5]. Rekonstruksi dari lempeng tektonik ini membantu untuk menjelaskan proses penting dalam perkembangan tektonik, seperti proses tumbukan (collision) dan proses regangan (extensional event) akibat pengaruh dari pergerakan lempeng. Sundaland dipisahkan dari Eurasia oleh proto - South China Sea (SCS) yang luas mungkin akibat dari spreading kerak lantai samudra pada Kala Mesozoikum.

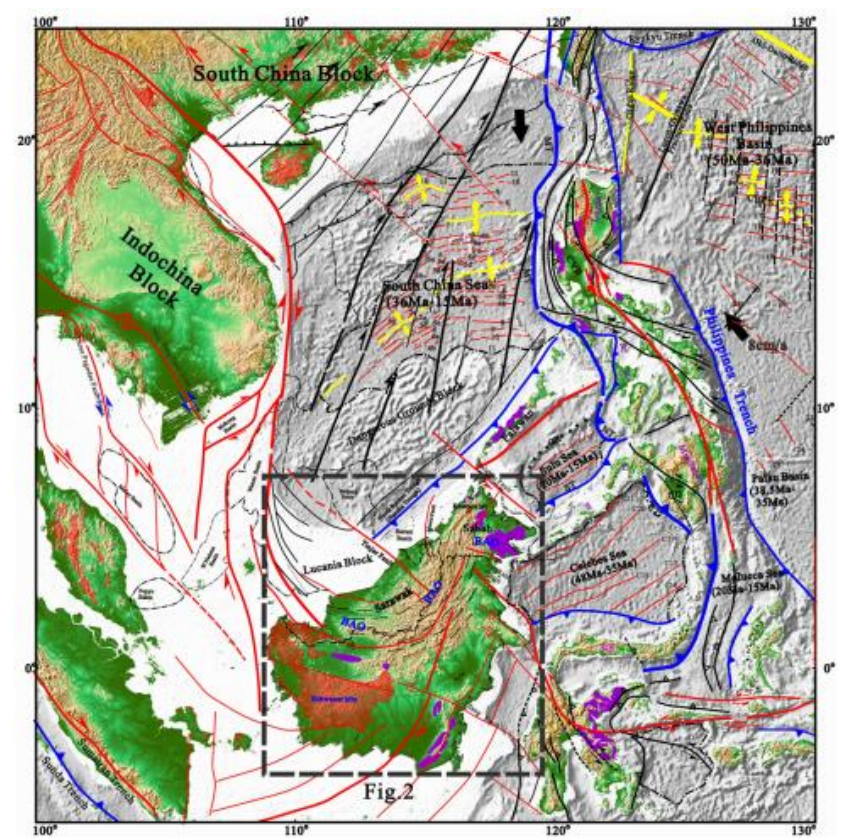

Gambar 1. Skematik tektonik wilayah Kalimantan Barat[4]. 
Tataan tektonik Pulau Kalimantan sangat kompleks (Gambar 4), hal ini menghasilkan batuan yang sangat beragam dan juga struktur geologi yang kompleks. Bagian utara Kalimantan didominasi oleh komplek akresi Crocker-Rajang Embaluh berumur Kapur dan Eosen-Miosen. Di bagian selatan komplek ini terbentuk cekungan Melawi-Ketungai dan cekungan Kutai selama Eosen Akhir, dan dipisahkan oleh zona ofiolit-melange LuparLubok Antu dan Boyan. Di bagian selatan pulau Kalimantan terdapat Schwanner Mountain berumur Kapur Awal-Akhir berupa batolit granit dan granodiorit yang menerobos batuan metamorf regional derajat rendah. Tinggian Meratus di bagian tenggara Kalimantan yang membatasi cekungan Barito dengan cekungan Asem-asem. Tinggian Meratus merupakan sekuens ofiolit dan busur volkanik Kapur Awal. Cekungan Barito dan Cekungan Kutai dibatasi oleh Adang flexure (Gambar 4).

Geologi daerah Gunung Niut dan sekitarnya termasuk ke dalam Peta Geologi Lembar Sambas-Siluas[6] dan Lembar Sanggau[7] dimana secara stratigrafi dari tua ke muda disusun oleh beberapa formasi batuan berikut: a) Formasi Seminis (PzTRs), merupakan batuan tertua yang tersingkap, tersusun atas batuan batusabak, filit dan batupasir, berumur Perm.

b) Batuan Gunungapi Sekadau (Trusk): terdiri dari basal, dolerit, andesit, tufa, breksi dan aglomerat, berumur Trias-Jura Akhir.

c) Kelompok Bengkayang ( $T r J b)$, terdiri dari sedimen karbonan.

d) Komplek Serabang ( $J K l s)$, terdiri dari batuan ultramafik, gabro, basalt malih, rijang, berumur Jura-Kapur.

e) Formasi Batupasir Kayan ( $T k k)$, terdiri dari batupasir kuarsa, serpih, batulanau sisipan konglomerat. Formasi berumur Kapur AtasOligosen Bawah.

f) Formasi Granit Puteh (Kup), terdiri dari granit dan adamelit yang berumur Kapur Atas yang menerobos formasi batupasir Kayan.

g) Batuan Terobosan Sintang (Toms), terdiri dari diorit, dasit, andesit dan granodiorit, mengintrusi batuan- batuan yang lebih tua yang berumur Oligosen Atas Miosen Bawah.

h) Batuan Gunung Api Serantak (Tes), terdiri dari batuan piroklastika dasitan, tufa lapilli, tufa kristal tufa litos, breksi tufaan, Rhyodasit, sebagian terubah.

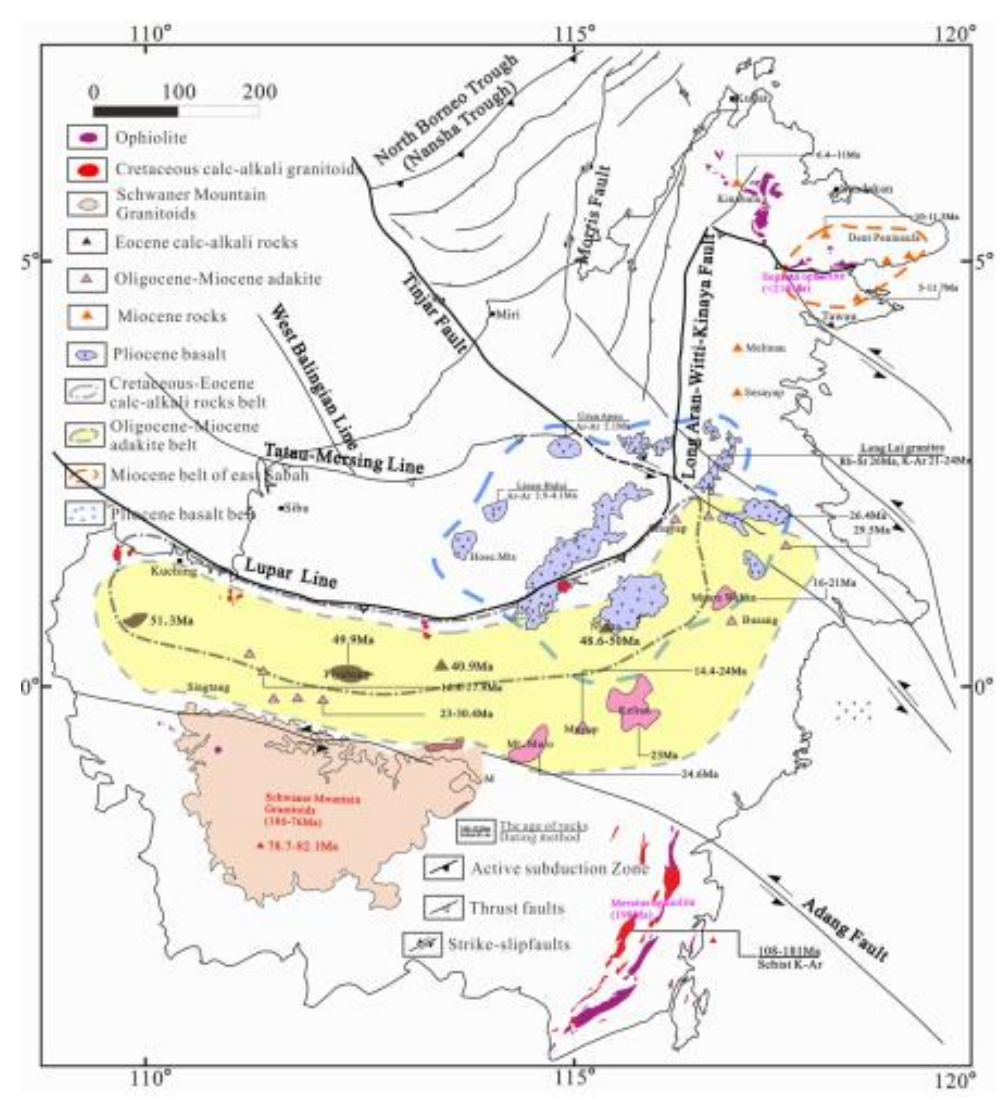

Gambar 2. Simplifikasi Tektonik regional Pulau Kalimantan[4]. 


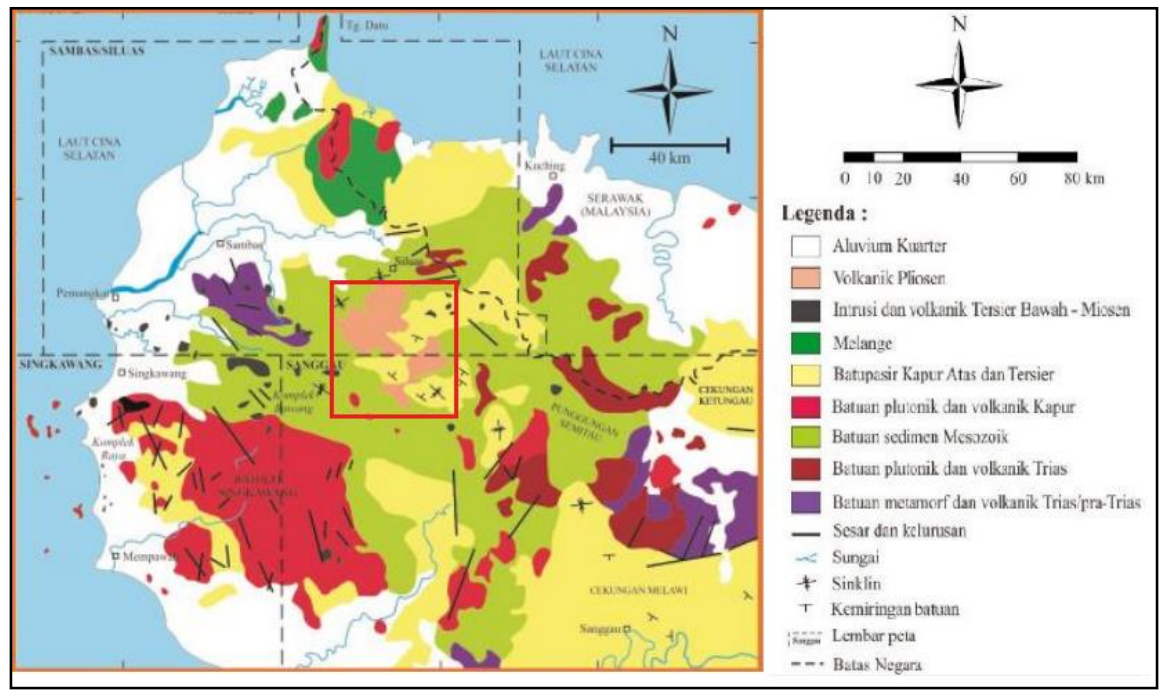

Gambar 3. Peta Geologi Regional Kalimantan Barat, termasuk lembar Sambas-Siluas[6] dan Sanggau[7]. Daerah Niut dan sekitarnya yang ditandai kotak merah.

i) Batuan Gunungapi Niut ( $T p n)$, terdiri dari basalt dan andesit piroksen, berumur Pliosen.

j) Endapan yang paling muda berupa endapan litoral $(Q c)$ dan endapan pantai $(Q p)$ : terdiri dari lumpur, pasir, kerikil, setempat gampingan, sisa tumbuhan, dan endapan aluvial serta rawa $(Q a)$ : terdiri dari lumpur, pasir, kerikil, sisa tumbuhan.

Pada daerah penyelidikan menurut jenis dan umur batuannya dapat dikelompokkan menjadi dua satuan berdasarkan peta geologi regional, yakni Batuan sedimen tersier dan batuan beku atau gunung api Pliosen. Masingmasing satuan batuan tersebut dari tua hingga muda yaitu Batupasir Kayan (Tkk) tersusun oleh batupasir kuarsa, serpih, batulanau, dan sisipan konglomerat berumur Paleosen-Miosen serta Batuan Gunung Api Niut (Tpn) yang terdiri atas basalt dan andesit piroksen berumur Pliosen (Gambar 5).

Kompleks Batuan Gunung Api Niut, dapat dibedakan menjadi beberapa gunung api, diantaranya komplek Seluas, Semadum dan Niut. Komplek Semadum memiliki bentuk dan sebaran produk gunung api yang khas, sehingga memerlukan kajian detil secara mineralogi maupun geokimia.

\section{METODOLOGI}

Penelitian diawali dengan kajian pustaka aspek magmatisme dan vulkanisme yang terbentuk di Kalimantan bagian barat. Interpretasi awal menggunakan citra DEM-
SRTM untuk mengetahui pola circular sebagai indikasi tubuh gunung api. Survei lapangan bertujuan untuk mengetahui lokasi singkapan, bentuk tubuh singkapan batuan, jenis batuan, deskripsi batuan (warna, tekstur, tingkat kristalisasi, struktur batuan, jenis mineral yang dapat teramati secara megaskopis, dan tingkat pelapukan). Pengambilan sampel batuan dilakukan secara selektif terhadap batuan yang dianggap mewakili tubuh batuan, segar, tidak lapuk dan tidak terubah.

Analisis sampel batuan di lakukan di laboratorium Pusat Teknologi Bahan Galian Nuklir, BATAN. Analisis petrografi menggunakan mikroskop polarisasi, sedangkan geokimia batuan menggunakan $X$ Ray Fluoresence (XRF). Analisis kimia batuan meliputi unsur-unsur oksida mayor $\left(\mathrm{SiO}_{2}\right.$, $\mathrm{Al}_{2} \mathrm{O}_{3}, \mathrm{Fe}_{2} \mathrm{O}_{3}, \mathrm{TiO}_{2}, \mathrm{FeO}, \mathrm{Na} 2 \mathrm{O}, \mathrm{K} 2 \mathrm{O}, \mathrm{CaO}$, $\left.\mathrm{MgO}, \mathrm{MnO}, \mathrm{P}_{2} \mathrm{O}_{5}\right)$ dan unsur jejak.

\section{HASIL DAN PEMBAHASAN}

\subsection{Geologi Gunung Api Daerah Penelitian}

Berdasarkan hasil pemetaan geologi permukaan secara umum daerah penelitian tersusun oleh batuan sedimen tua dan batuan gunung api. Pada daerah penelitian lebih dominan dijumpai batuan gunung api. Pemetaan geologi gunung api teridentifikasi adanya satu sumber gunung api yaitu Khuluk Semadum atau Gunung Api Semadum dimana produk batuannya dikelompokkan menjadi lima satuan batuan, yaitu satuan lava andesit basalt 
berstruktur vesikuler-skoria, lava andesit berstruktur masif, satuan tuf, satuan breksi piroklastik dengan fragmen andesit berukuran bom dan blok, serta berfragmen lapili-tuf, serta satuan kubah lava andesit porfiri, sedangkan endapan sekunder berupa endapan longsoran gunung semadum. Selain itu terdapat Gumuk Duyung yang memiliki satu produk berupa basalt. Batuan non-volkanik yang ditemukan berupa batupasir kuarsa, batupasir feldspar, dan konglomerat.

Secara rinci, geologi daerah penelitian dibedakan menjadi beberapa satuan, dari tua hingga paling muda sebagai berikut:

- Satuan Batupasir Kuarsa Pisak (Bpkp): Litologi yang berkembang berupa batupasir kuarsa, batupasir feldspar, dan konglomerat. Satuan batuan ini tersebar mengelilingi gunung api Semadum dan ketebalan singkapan berkisar 3-20 m. Secara megaskopis litologi ini mempunyai ciri fisik warna segar kuning kecoklatan dan sedikit agak keputihan dan warna lapuk hitam kehijuan, struktur masif, ukuran butir pasir sedang-sangat kasar, kemas tertutupterbuka, sortasi baik-buruk, komposisi fragmen terdiri dari kuarsa, feldspar, mineral opak dan litik.

- Satuan Lava Andesit-Basalt VesikulerSkoria Semadum (Lavss): Litologi yang berkembang berupa lava andesit-basalt berstruktur vesikuler-skoria dengan sebaran di sekitar area kaki Semadum dan dataran area gunung Semadum dengan sebaran relatif ke arah barat dengan pelamparan sebaran sangat luas. Ketebalan singkapan dilapangan 2-5 m. Secara megaskopis satuan batuan ini dicirikan dengan warna segar abu-abu agak kehitaman dan warna lapuk coklat kemerahan serta sedikit agak kekuningan (warna karat), struktur vesikuler dan skoria, tekstur porfiroafanitik dan hipokristalin dan sebagian menunjukkan tekstur khusus yaitu trakhitik dengan komposisi plagioklas dan piroksen.

- Satuan Lava Andesit Masif Semadum (Lams): Litologi yang berkembang berupa lava andesit berstruktur masif dengan sebaran hanya di sekitar area punggungan, lembah, dan sekitar kaki Gunung Api Semadum serta dijumpai di dekat puncak berupa bongkah dan sudah terlapukkan.
Ketebalan singkapan 3-7 m. Secara megaskopis satuan batuan ini dicirikan dengan warna segar abu-abu cerah relatif agak kehitaman sebagian telah mengalami oksidasi berwarna merah pucat dan warna lapuk coklat kehijauan, struktur masif dan sebagian menunjukkan berlembar (sheeting joint), tekstur porfiroafanitik dan hipokristalin dengan komposisi plagioklas dan piroksen.

- Satuan Tuf Semadum (Tfs): Pada satuan batuan ini litologi yang berkembang berupa tuf berstruktur masif dengan sebaran hanya di area sekitar kaki Gunung Api Semadum serta dijumpai di bagian lembah. Ketebalan singkapan 3-12 m. satuan batuan ini dicirikan dengan warna segar putih cerah keabu-abuan, warna lapuk coklat kehitaman dan kekuningan, struktur masif, tekstur piroklastik dengan ukuran butir abu, fragmen berkomposisi abu, mineral opak, plagioklas, lithik dan gelas.

- Satuan Breksi Piroklastik Semadum (Bprs): Pada satuan batuan ini litologi yang berkembang berupa breksi dengan fragmen andesit berupa bom dan blok serta breksi dengan fragmen lapili/tuf dengan sebaran di area punggungan lembah serta sekitar puncak dan kaki Gunung Api Semadum. Ketebalan singkapan 3-40 m. Litologi secara megaskopis memiliki ciri fisik warna segar pada fragmen andesit abu-abu kehitaman dan fragmen lapili/tuf putih cerah keabu-abuan, warna lapuk coklat hijau kemerahan dan sedikit kehitaman, struktur secara umum berstruktur fragmental, pada fragmen andesit tekstur berdasarkan granularitas porfiroafanitik, tekstur berdasarkan derajat kristalisasi hipokristalin, bentuk kristal equigranular, subhedral-anhedral, dan prismatik, fragmen andesit berkomposisi plagioklas, piroksen dan biotit. Pada fragmen lapili/tuf bertekstur piroklastik dengan ukuran butir abu berkomposisi abu, mineral opak, lithik, plagioklas dan glass. Ukuran dari fragmen breksi piroklastik yaitu fragmen andesit 10$50 \mathrm{~cm}$ dan bentuk fragmen relatif kotak dengan menyudut relatif meruncing serta permukaan halus, oval dengan permukaan relatif agak kasar serta ada retakan menyerupai pecahan roti dan relatif membulat dengan permukaan sangat kasar. 
Pada fragmen tuf/lapili ukuran fragmen 2-13 $\mathrm{cm}$ dengan bentuk fragmen kotak-kotak dan fragmen dengan ukuran kecil bentuk relatif agak membulat.

- Satuan Kubah Lava Andesit Porfiri Semadum (Kls): Litologi yang berkembang berupa kubah lava andesit porfiri dengan sebaran hanya di sekitar area dekat puncak gunung api Semadum. Ketebalan singkapan $45 \mathrm{~m}$ dan singkapan relatif membentuk setengah lingkaran. Secara megaskopis litologi mempunyai ciri fisik berupa warna segar abu-abu cerah relatif agak kehitaman dan warna lapuk hijau kecoklatan, struktur masif dan sebagian menunjukkan berlembar (sheeting joint), tekstur porfiroafanitik dan hipokristalin, komposisi plagioklas, piroksen, dan biotit.

- Satuan Basalt Duyung (Bld): Satuan ini terdapat litologi berupa basalt dengan area yang tidak terlalu luas. satuan ini di jumpai di Bukit Duyung yang ada di lokasi penelitian. ketebalan singkapan berkisar 2$3 \mathrm{~m}$ dan mayoritas telah mengalami pelapukan intensif menjadi tanah. Secara megaskopis litologinya memiliki ciri fisik berupa warna segar hitam dan warna lapuk coklat agak kekuningan dan kemerahan, struktur masif, tekstur afanitik dan hipokristalin, komposisi berupa mineral mafik dan plagioklas.

- Satuan Endapan Longsoran Semadum (Els): Satuan ini merupakan hasil dari produk Gunung Api Semadum yang telah mengalami proses longsoran sehingga produk ini mengalami perombakan acak akibatnya material tercampur dengan berbagai produk gunung api berupa bongkah lava masif, tuf, bongkah kubah lava dan breksi piroklastik dengan diameter yang beragam dari $2 \mathrm{~cm}-4$ m. satuan berada di Selatan daerah penelitian dengan arah sebaran ke Barat.

Peta Geologi daerah penelitian terdapat pada Gambar 6.

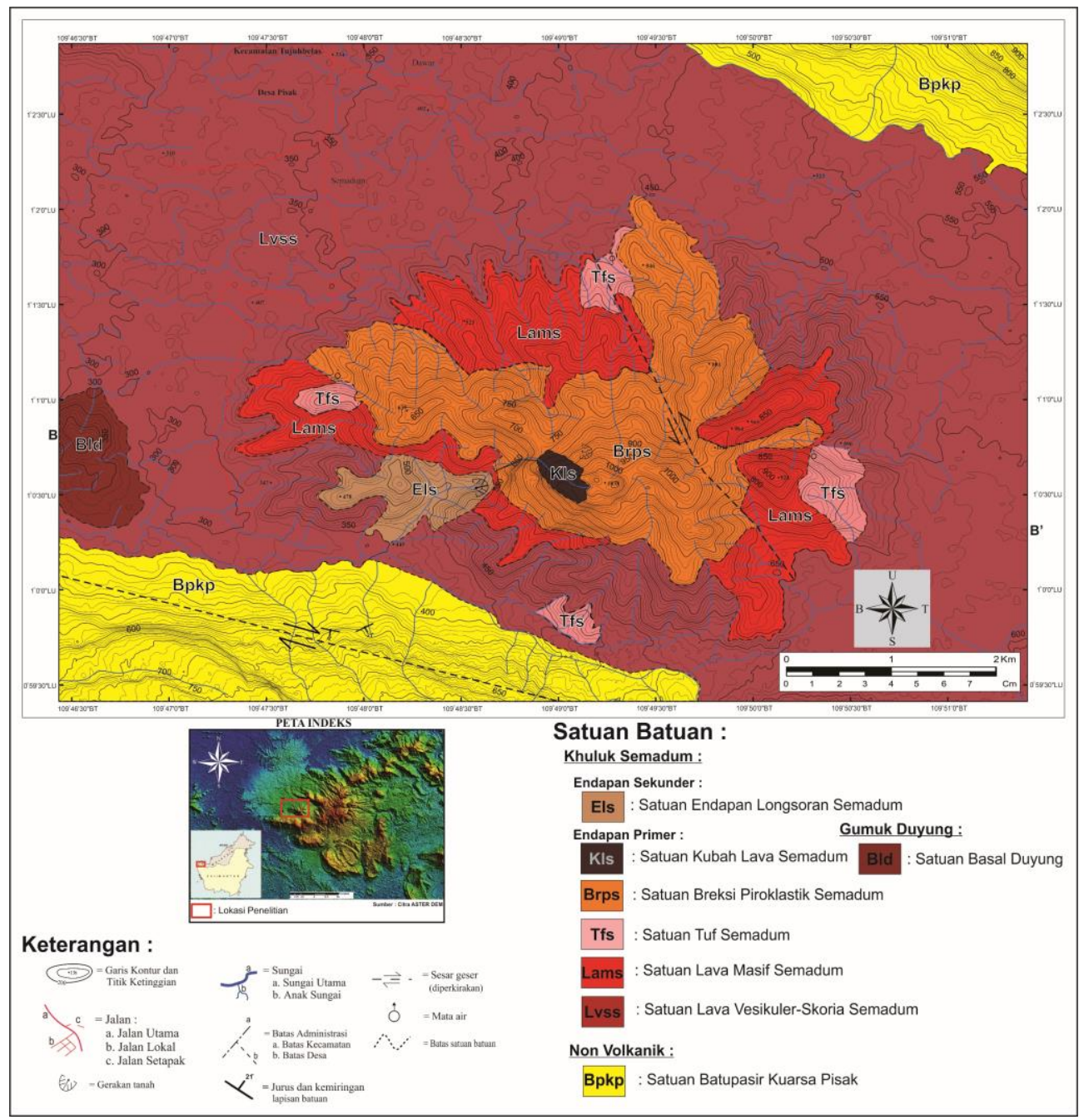

Gambar 6. Peta Geologi Gunung Api Daerah Penelitian. 
Pengambilan sampel batuan dilakukan pada batuan dari Gunung Api Semadum yang terdiri dari produk piroklastika, antara lain tuf, breksi piroklastika dengan fragmen bom dan blok berupa andesit dan breksi piroklastika dengan fragmen tuf-lapili, produk lava berupa lava andesit-basalt vesikuler-skoria, lava andesit trakhitik masif dan kubah lava andesit porfiri.

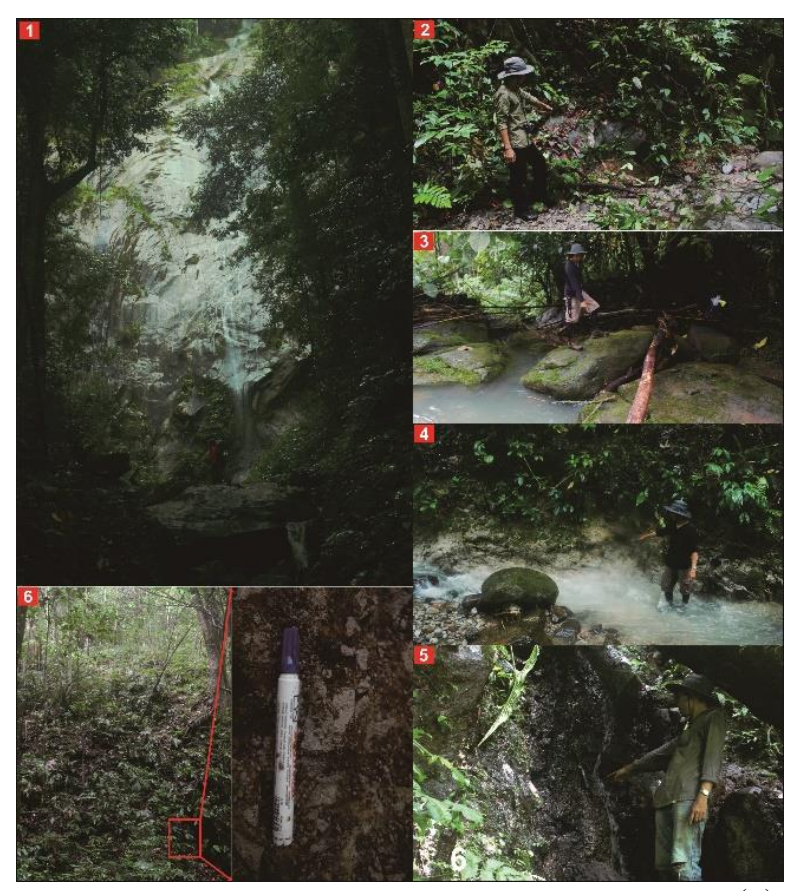

Gambar 7. Penampakan produk gunung api Semadum (1) Kubah lava (2). Lava masif (3) Lava vsesikuler-skoria (4). Tuf (5). Breksi piroklastik (6) Breksi piroklastik dengan frgamen tuf-lapili.

\subsection{Petrologi dan Petrografi Produk Batuan Gunung Api Semadum}

Produk piroklastika antara lain tuf, breksi piroklastika dengan fragmen bom dan block berupa andesit dan breksi piroklastika dengan fragmen tuf-lapili pada sayatan tipis menunjukkan fragmen juvenile dan cognate litik (Gambar 8)

Fragmen juvenile dianggap berasal langsung dari magma yang terdiri dari partikel atau fragmen yang tertinggal dari lelehan yang telah mendingin, atau kristal yang berada di magma sebelum letusan[8]. Fragmen juvenile yang hadir dalam produk gunung api Semadum yaitu juvenile tachylite merupakan fragmen glass vulkanik berwarna gelap dan diisi dengan mineral buram, umumnya keberadaan tachylite mengindikasikan lambatnya pendinginan setelah fragmentasi, misalnya akibat pengaruh udara[9]. Terdapat fragmen juvenile pyrogenic crystals berupa mineral plagioklas dan mafik yang terdapat tekstur rim opacitic akibat pengaruh pelepasan air. Kristal pirogenik dianggap sebagai fragmen awal dan mewakili dari proses kristalisasi sebelum fragmentasi. Kristal didefinisikan sebagai kristal bebas dan fragmen kristal yang dilepaskan ketika letusan eksplosif. Hadirnya fragmen juvenile sideromelane merupakan kehadirannya menunjukkan pendinginan yang cepat, lingkungan yang relatif dingin, seperti material panas yang didinginkan dalam air ataupun keluarnya material panas, seperti air mancur api (misalnya rambut Pele)[10].

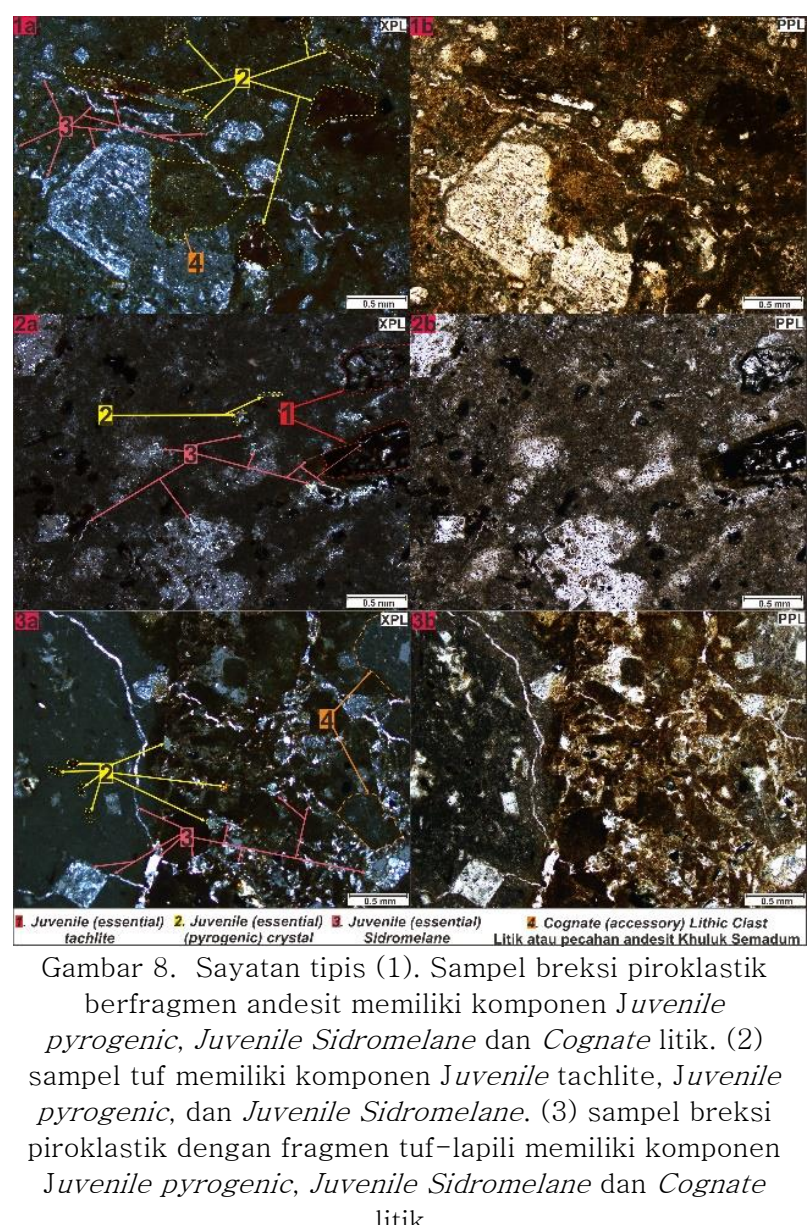
litik.

Glass shard atau rambut Pele yang terdapat pada breksi piroklastik dan tuf ini menunjukkan tipikal erupsi tipe strombolian yang menghasilkan gelas berbentuk rambut yang menyerupai air mata[11]. Hal ini dikarenakan letusan tipe strombolian akan melontarkan abu gunung api secara memancar atau menyerupai air mancur yang berupa material panas berbentuk cair maupun padat. 
Penulis meyakini bahwa bentukan dari glass shard merupakan tekstur sisa dari letusan tipe strombolian gunung api Semadum. Terdapat juga cognate accessory lithik clast berupa sisa litik andesit dan tuf yang dihasilkan dari erupsi sebelumnya, dimana kondisinya sudah lapuk. Penulis meyakini bahwa fragmen ini merupakan hasil dari erupsi sebelumnya karena bentuknya relatif masih besar, memiliki tekstur yang mirip dengan lava andesit Semadum, dan kondisinya telah lapuk memungkinkan bahwa sebelumnya litik ini pernah terekspos di permukaan sebelumnya.

Secara petrografi produk lava antara lain lava dasitik-basaltik vesikler-skoria, lava andesit masif, kubah lava dasitik porfiri. (Gambar 9). Berdasarkan pengamatan petrografi lava andesit-basalt vesikuler-skoria memiliki tekstur glomeroporfiritik. Kandungan mineral piroksen yang tidak terlalu banyak menandakan magma yang relatif encer. Dijumpai kehadiran mineral plagioklas jenis andesin dan mineral olivin yang hadir pada lava merupakan xenokris dengan batas kristal anhedral sehingga diperkirakan mengalami diferensiasi magma yang cukup intens. Struktur khas pada lava berupa vesikuler-skoria yang mengindikasikan kandungan gas yang tinggi.

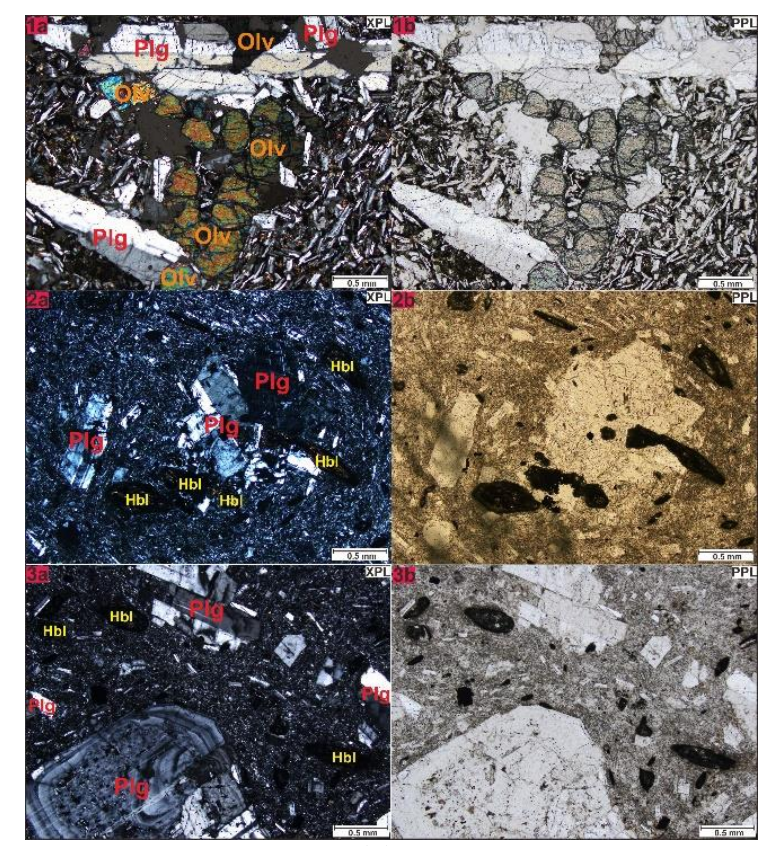

Gambar 9. Sayatan tipis (1).sampel lava andesit-basal berstruktur vesikuler-skoria memiliki komposisi plagioklas (Plg), Olivin (Olv) dan Piroksen (Prk). (2) sampel lava andesit berstruktur masif memiliki komposisi plagioklas (Plg), hornblenda ( $\mathrm{Hbl}$ ) dan masa dasar mikrolit glass vulkanik. (3) sampel kubah lava dasit porfiri memiliki komposisi plagioklas (Plg), hornblenda (Hbl) dan masa dasar mikrolit plagioklas dan glass vulkanik.
Lava berstruktur masif terdapat mineral plagioklas jenis andesin merupakan mineral yang paling dominan, menandakan diferensisi magma yang cukup intens. Terdapat mineral hornblenda yang menunjukkan adanya tekstur rim opacitic merupakan struktur umum mineral terhidrasi akibat melepaskan air yang terikat secara struktural ke magma sebagai respons terhadap penurunan tekanan air di magma saat naik ke permukaan. Proses pembentukan tepi rim opacitic dapat digambarkan sebagai proses devolatilisasi atau perubahan padatan menjadi gas. Sementara itu, mikrolit gelas vulkanik hadir sebagai masa dasar menunjukkan tekstur khas trakitik menunjukkan dari suatu lava yang mengalir.

Kubah lava menunjukkan tekstur porfiroafanitik, mineral plagioklas jenis andesin merupakan mineral yang paling dominan menandakan diferensisi magma yang cukup intens. Pada plagioklas juga terdapat tekstur zoning menunjukkan pola lapisan radial mineral ke arah luar mengindikasikan pembentukan kubah lava terkena pengaruh aktivitas influks magma yang mengubah komposisi mineral pada bagian terluar tubuh mineral yang melingkupinya. mineral hornblenda yang menunjukkan adanya tekstur rim opacitic merupakan struktur mineral terhidrasi akibat melepaskan air yang terikat secara struktural ke magma sebagai respons terhadap penurunan tekanan air di magma saat naik ke permukaan. Sementara itu, mikrolit gelas vulkanik dan plagioklas hadir sebagai masa dasar. Tekstur sieve pada fenokris plagioklas yang mengalami lelehan dan mengkristalkan mineral di bagian tersebut. Tekstur ini terbentuk karena proses pencampuran magma yang melelehkan plagioklas yang sebelumnya lebih dahulu terbentuk. fenokris plagioklas dan dikelilingi mikrolit plagioklas yang mengkristal secara acak menunjukkan fenokris terbentuk terlebih dahulu yang dilanjutkan dengan mikrolit plagioklas, kondisi ini umumnya mencirikan daerah pembekuan hipabisal.

\subsection{Geokimia Produk Batuan Gunung Api Semadum}

Dari seluruh contoh batuan produk Semadum yang terambil dipilih kondisi sampel yang segar yang dianggap nilai hasil pengukuran akurat yaitu jumlah total oksida 
mayor mendekati nilai 100 wt. 100\% dengan toleransi $\pm 2 \%$. Hasil analisis X-Ray Fluorescence (XRF) pada Tabel 1. Dari hasil geokimia tersebut selanjutnya di analisis oksida mayor dengan diagram $\mathrm{SiO}_{2}$ vs $\mathrm{K}_{2} \mathrm{O}$ untuk menentukan afanitas magma[12] sedangkan untuk mengetahui jenis batuan berdasarkan sifat geokimianya digunakan klasifikasi TAS (Total Alkali Silica) dengan diagram $\mathrm{K}_{2} \mathrm{O}+\mathrm{Na}_{2} \mathrm{O}$ vs $\mathrm{SiO}_{2}[13]$.

Tabel 1. Hasil Analisis XRF Batuan

\begin{tabular}{|c|c|c|c|c|c|c|c|c|}
\hline \multicolumn{9}{|l|}{ Oksida } \\
\hline Mayor & SDN & SDN & SDN & SDN & SDN & $\begin{array}{c}\text { SDN } \\
34\end{array}$ & SDN & SDN \\
\hline & 03 & 66 & & 125 & 45 & 34 & 138 & \\
\hline $\mathrm{SiO}_{2}$ & 52,39 & 51,42 & 51,24 & 69,23 & 69,73 & 52,86 & 53,32 & 52,69 \\
\hline $\mathrm{TiO}_{2}$ & 1,29 & 1,44 & 1,40 & 0,38 & 0,40 & 1,16 & 1,15 & 1,22 \\
\hline $\mathrm{Al}_{2} \mathrm{O}_{3}$ & 20,19 & 19,00 & 20,83 & 15,77 & 14,75 & 19,97 & 20,73 & 20,08 \\
\hline $\mathrm{Fe}_{2} \mathrm{O}_{3}$ & 10,45 & 11,72 & 11,05 & 3,14 & 3,23 & 9,87 & 10,51 & 9,58 \\
\hline $\mathrm{MnO}$ & 0,12 & 0,14 & 0,14 & 0,59 & 0,54 & 0,12 & 0,12 & 0,11 \\
\hline $\mathrm{MgO}$ & 2,90 & 2,99 & 2,69 & 0,53 & 0,87 & 2,86 & 1,17 & 3,02 \\
\hline $\mathrm{CaO}$ & 6,90 & 7,40 & 6,96 & 3,23 & 3,26 & 6,83 & 7,06 & 6,74 \\
\hline $\mathrm{Na}_{2} \mathrm{O}$ & 4,96 & 5,05 & 4,89 & 3,89 & 3,89 & 5,39 & 5,12 & 5,65 \\
\hline $\mathrm{K}_{2} \mathrm{O}$ & 0,55 & 0,59 & 0,47 & 2,07 & 2,08 & 0,70 & 0,53 & 0,55 \\
\hline $\mathrm{P}_{2} \mathrm{O}_{5}$ & 0,25 & 0,25 & 0,32 & 0,26 & 0,26 & 0,24 & 0,19 & 0,23 \\
\hline LOI & 0,13 & 0,07 & 0,25 & 0,89 & 0,99 & 0,02 & 0,10 & 0,12 \\
\hline Total & 100,1 & 100,1 & 100,3 & 100,0 & 100,0 & 100,0 & 100,0 & 100,0 \\
\hline \multicolumn{9}{|c|}{ Unsur Jejak (ppm) } \\
\hline $\mathrm{V}$ & 0,22 & 0,3 & 0,24 & 0,49 & 0,77 & 0,19 & 0,21 & 0,19 \\
\hline $\mathrm{Cr}$ & 0,26 & 0,4 & 0,34 & 0,27 & 0,96 & 0,27 & 0,33 & 0,22 \\
\hline $\mathrm{Co}_{\mathrm{O}}$ & 0,22 & 0,29 & 0,8 & 0,8 & 0,8 & 0,24 & 0,55 & 0,26 \\
\hline $\mathrm{Ni}$ & 0,92 & 0,12 & 0,92 & 0,24 & 0,25 & 0,96 & 0,13 & 0,92 \\
\hline $\mathrm{Cu}$ & 0,71 & 0,9 & 0,57 & 0,1 & 0,26 & 0,68 & 0,79 & 0,61 \\
\hline $\mathrm{Zn}$ & 0,98 & 0,13 & 0,11 & 0,72 & 0,66 & 0,94 & 0,97 & 0,92 \\
\hline Ga & 0,18 & 0,23 & 0,22 & 0,17 & 0,2 & 0,2 & 0,17 & 0,14 \\
\hline $\mathrm{Rb}$ & 0,11 & 0,13 & 0,6 & 0,62 & 0,6 & 0,13 & 0,1 & 0,1 \\
\hline $\mathrm{Sr}$ & 0,22 & 0,24 & 0,25 & 0,41 & 0,41 & 0,22 & $\begin{array}{c}0,22 \\
\end{array}$ & 0,21 \\
\hline $\mathrm{Y}$ & 0,22 & 23,6 & 0,23 & 0,3 & 0,14 & 0,19 & 0,18 & 0,24 \\
\hline $\mathrm{Zr}$ & 0,13 & 0,14 & 0,13 & 0,22 & 0,21 & 0,11 & 0,1 & 0,11 \\
\hline $\mathrm{Nb}$ & 0,1 & 0,11 & 0,1 & 0,13 & 0,13 & 0,9 & 0,9 & 0,8 \\
\hline $\mathrm{Ba}$ & 0,16 & 0,17 & 0,18 & 0,46 & 0,46 & 0,11 & 0,11 & 0,18 \\
\hline $\mathrm{La}$ & 0,9 & 0,12 & 0,16 & 0,75 & 0,48 & 0,9 & 0,11 & 0,9 \\
\hline $\mathrm{Ce}$ & 0,12 & 0,15 & 0,22 & 0,97 & 0,83 & 0,12 & 0,14 & 0,12 \\
\hline $\mathrm{Pr}$ & 0,4 & 0,8 & 0,7 & 0,33 & 0,25 & 0,8 & 0,9 & 0,8 \\
\hline $\mathrm{Nd}$ & 0,5 & 0,15 & 0,16 & 0,82 & 0,57 & 0,16 & 0,18 & 0,16 \\
\hline $\mathrm{Sm}$ & 0,14 & 0,11 & 0,33 & 0,12 & 0,8 & 0,16 & 0,17 & 0,25 \\
\hline Er & LOD & LOD & LOD & LOD & LOD & LOD & LOD & LOD \\
\hline $\mathrm{Yb}$ & LOD & LOD & LOD & LOD & LOD & LOD & LOD & LOD \\
\hline $\mathrm{Hf}$ & 0,4 & 0,4 & 0,2 & 0,7 & 0,2 & 0,4 & 0,2 & 0,4 \\
\hline $\mathrm{Ta}$ & 0,2 & 0,2 & 0,2 & 0,4 & 0,2 & 0,2 & 0,2 & $\overline{0,2}$ \\
\hline Wo & 0,1 & 0,1 & 0,1 & 0,1 & 0,1 & 0,1 & 0,1 & 0,1 \\
\hline $\mathrm{Pb}$ & 0,9 & 0,4 & 0,4 & 0,5 & 0,12 & 0,4 & 0,2 & 0,6 \\
\hline $\mathrm{Th}$ & 0,1 & $\begin{array}{l}\text { LOD } \\
\end{array}$ & LOD & 0,1 & 0,1 & 0,1 & LOD & 0,1 \\
\hline $\mathrm{U}$ & LOD & LOD & LOD & 0,1 & 0,4 & LOD & LOD & LOD \\
\hline
\end{tabular}

Berdasarkan hasil analisis dengan menggunakan XRF, maka dapat diketahui afinitas magma pada saat pembentukan batuan tersebut (Gambar 10 dan 11).

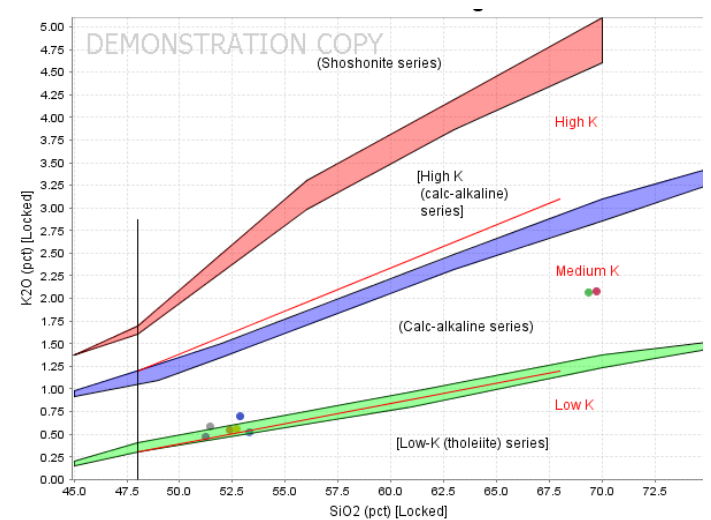

Gambar 10. Diagram $\mathrm{SiO}_{2}$ vs $\mathrm{K}_{2} \mathrm{O}$ pada sampel terpilih di Gunung Semadum [12].
Berdasarkan diagram $\mathrm{SiO}_{2}$ vs $\mathrm{K}_{2} \mathrm{O}$ dapat diketahui bahwa afinitas magma penyusun batuan di kompleks gunung Semadum adalah seri calc-alkaline, dimana seri ini hanya dapat terbentuk pada zona konvergen atau dipengaruhi oleh interaksi magma dengan kerak benua atau kerak samudera[12].

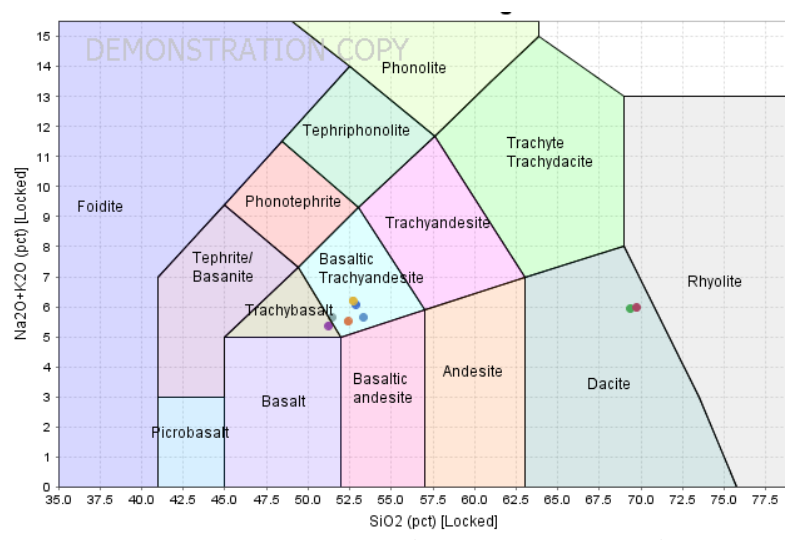

Gambar 11. Diagram TAS (Total Alkali Sicica) yaitu diagram $\mathrm{SiO}_{2}$ vs $\mathrm{K}_{2} \mathrm{O}+\mathrm{Na}_{2} \mathrm{O}$ pada sampel terpilih di Gunung Semadum[13].

Berdasarkan hasil analisis geokimia batuan menggunakan diagram TAS, diketahui bahwa batuan penyusun Gunung Api Semadum merupakan batuan trakhit, basalt trakhiandesit dan periode terakhir yang merupakan bentukan kubah sub-vulkanik yang tersusun oleh batuan dasit.

\subsection{Sebaran produk dan bahaya Gunung Api Semadum terhadap calon Tapak PLTN.}

Gunung Semadum merupakan Gunung api yang terletak di Desa Pisak, Kecamatan TujuhBelas, Bengkayang, Kalimantan Barat yang masih memiliki bentukan lembah dan kerucut yang sangat baik.

Berdasarkan hasil pemetaan geologi detail yang dilakukan, gunung api ini diinterpretasikan terbentuk pada beberapa periode, yaitu periode erupsi dan periode intrusi yang membentuk batuan intrusi yang sangat dangkal/ sub-vulkanik. Pada fase erupsi, gunung api Semadum menghasilkan produk letusan berupa lava, tuf (abu vulkanik) dan breksi vulkanik, sedangkan pada fasa intrusif aktivitas Gunung Api Semadum menghasilkan kubah lava dasitik dengan batuan dasit porfir.

Produk gunung api yang membahayakan tapak PLTN diantaranya, aliran lava, aliran 
piroklastik, aliran debris, breksi lahar dan produk jatuhan piroklastik seperti tuf, lapilli, bomb dan blok[14]. Produk ini dapat dihasilkan oleh aktivitas erupsi gunung api[12].

Berdasarkan hasil pemetaan geologi detil skala 1/25.000 pada produk Gunungapi Semadum, diketahui bahwa sebaran aliran lava Semadum mencapai sekitar $17 \mathrm{~km}$ dari pusat erupsi, hal ini menunjukkan bahwa lava memiliki viskositas yang tinggi sehingga mobilitasnya sangat kecil. Produk piroklastik yang dihasilkan tidak banyak yang ditemukan. Breksi piroklastik dan tuf hanya dijumpai di kaki Gunung Semadum. Hal ini menunjukkan VEI dari gunung semadum sangat rendah $<2$, dengan sifat letusan yang cenderung efusif[15]. Potensial bahaya yang ditimbulkan oleh aktivitas Gunung Api Semadum lebih bersifat lokal. Hal ini dikarenakan jenis magma yang bersifat basaltic hingga intermediet [16]

Berdasarkan jenis produk dan sebarannya yang tidak begitu luas, maka dapat diketahui bahwa pada jarak $115 \mathrm{~km}$ dari calon tapak Pantai Gosong, aktivitas Gunung Semadum tidak memberikan dampak bahaya gunung api terhadap tapak PLTN. Tetapi untuk mengetahui lebih pasti periode aktivitas magma di daerah ini sangat diperlukan pentarikhan umur absolut.

\section{KESIMPULAN}

Kalimantan barat merupakan daerah yang memiliki potensi bahaya gunung api sangat kecil dan sangat baik untuk dipilih sebagai rencana calon tapak PLTN. Keterdapatan gunung api muda di daerah Kalimantan Barat terletak di bagian timur Kabupaten Bengkayang yang berjarak 95-130 km dari lokasi calon tapak. Gunung Semadum merupakan salah satu gunung api muda yang berumur Pliosen yang berjarak $115 \mathrm{~km}$ dari lokasi calon tapak PLTN, tersusun oleh lava andesit-basalt berstruktur vesikuler-skoria, lava andesit berstruktur masif, batuan piroklastika berupa breksi piroklastik dengan fragmen andesit (bom dan blok), breksi lapili/tuf, dan kubah lava. Kompleks ini memiliki afinitas calc-alkalin. Berdasarkan sifat magma dan sebaran produknya, Gunung Api Semadum tidak memiliki potensi bahaya gunung api terhadap calon tapak PLTN.

\section{SARAN / REKOMENDASI}

Untuk mengetahui umur periode magmatisme Gunung Api Semadum dan sekitarnya perlu dilakukan pentarikhan umur absolut dengan metode radiometrik pada beberapa sampel terpilih. Data yang diperoleh akan menjadi acuan dalam studi ini agar dapat memberikan gambaran lebih detail terkait kajian umur magmatisme Kalimantan bagian barat.

\section{UCAPAN TERIMA KASIH}

Pada kesempatan ini penulis mengucapkan terimakasih yang sebesarbesarnya kepada Pusat Kajian Sistem Energi Nuklir (PKSEN) dan Pusat Teknologi Bahan Galian Nuklir (PTBGN) Badan Tenaga Nuklir Nasional yang telah memberikan fasilitas dan pendampingan selama berlangsungnya kegiatan lapangan di Kabupaten Bengkayang, Provinsi Kalimantan Barat.

\section{DAFTAR ACUAN}

[1] Bapeten, Peraturan Kepala Badan Pengawas Tenaga Nuklir Nomor 5 Tahun 2015 Tentang Evaluasi Tapak Instalasi Nuklir untuk Aspek Kegunungapian. Badan Pengawas Tenaga Nuklir, Jakarta, 2015.

[2] H. Suntoko dan J. Melawati, "Identifikasi Lokasi Gambut untuk Kajian Calon Tapak di Kalimantan Barat," dalam Prosiding Seminar Geologi Nuklir dan Sumber Daya Tambang 2014, 2014, pp. 109-116.

[3] H. Suntoko, "Identifikasi Daerah Interes Calon Tapak PLTN Kalimantan Barat Berdasarkan Kriteria Umum,” Eksplorium, vol. 35, no. 1, pp. 5768, 2014.

[4] I. Metcalfe, "Tectonic framework and Phanerozoic evolution of Sundaland," Gondwana Res., vol. 19, no. 1 , pp. 3-21, 2011.

[5] R. Hall and G. J. Nichols, "Cenozoic sedimentation and tectonics in Borneo: climatic influences on orogenesis," Geol. Soc. London, Spec. Publ., vol. 191, no. 1, pp. 5-22, 2002.

[6] E. Rusmana dan P. E. Pieters, "Peta Geologi Lembar Sambas/Siluas, Kalimantan (1317-1417) Skala 1:250.000". Bandung, Indonesia : Pusat Penelitian dan Pengembangan Geologi,1993.

[7] S. Supriatna, U. Margono, Sutrisno, P. E. Pieters, and R. P. Langford, "Peta Geologi Lembar Sanggau, Kalimantan (1416) Skala 1:25.000.”. Bandung, Indonesia : Pusat Penelitian dan Pengembangan Geologi, 1993.

[8] R. A. F. Cas and J. V. Wright. 1988. Volcanic Successions Modern and Ancient: a geological approach to processes, products and successions. 
Netherlands: Springer, 528.

[9] R. V. Fisher and H. U. Schmincke. 1984. Pyroclastic Rocks. 2557. Berlin: Springer-Verlag.

[10] J. McPhie, M. Doyle, and R. Allen. 1993. Volcanic Textures. Australia: University of Tasmania.

[11] S. Bronto, 2013. Geologi Gunung Api Purba, Edisi Pertama. Bandung: Badan Geologi.

[12] M. Wilson. 1989. Igneous Petrogenesis: A Global Tectonic Approach, First Edition. Nedherlands: Springer.

[13] M. J. Le Bas and A. L. Streckeisen, "The IUGS systematics of igneous rocks," J. Geol. Soc. London., vol. 148, no. 5, pp. 825-833, 1991.

[14] I. G. Sukadana, Y. S. B. Susilo, A. Heriwaseso, and E. E. Alhakim, "Probabilistic Analysis of theLaharic Hazard Assessment on Experimental Power Reactor, Puspiptek Area, Serpong," J. Phys. Conf. Ser., vol. 1363, no. 1, pp. 1-8, 2019.

[15] L. R. Goode, H. K. Handley, S. J. Cronin, and M. Abdurrachman, "Insights into eruption dynamics from the 2014 pyroclastic deposits of Kelut volcano, Java, Indonesia, and implications for future hazards," J. Volcanol. Geotherm. Res., 2018.

[16] I. Tilling, "Volcanic Progress Hazards and Mitigation- and Problems," Rev. Geophys., vol. 27, no. 2, pp. 237-269, 1989. 